\title{
Meeting the Man We Are Learning from: Interview with Patrick Casement
}

\author{
Gabriela Mercado and Patrick Casement
}

Psychotherapist, AUCKLAND, Psychoanalyst, LONDON

\begin{abstract}
Patrick Casement is a psychoanalyst and psychotherapist with over fifty years of clinical experience. For decades, he has run a private practice from the front room of his London home where Gabriela Mercado had the privilege to meet him. In an open conversation Patrick explores his work with patients, his personal journey, and his latest book. The space he always worked from is now changed, but the atmosphere remains filled with lively memories. Patrick's recollection of his patients is vivid because - as Andrew Samuels refers to him - he is a true pioneer of today's relational psychotherapy thinking and as such, he has allowed his work to truly touch his life.
\end{abstract}

\section{Whakarāpopotonga}

Ko Pāteriki Kāhimana, he mātanga kaitātari hinengaro, kaiwhakaora hinengaro, whiwhi wheako haumanu neke atu o te rima tekau tau. E hia tekau tau a ia e whakahaere wāhi mahi motuhake ana mai i te taiwhanga whakamua o tōna whare I Rānana, te wāhi i waimarie ai a Kāpiriera Mēkaro ki te tūtaki i a ia. I roto i tētahi kōrero matawhānui ka tūhurahia e Pāteriki āna mahi i te taha o āna tūroro, tana hīkoi whaiaro me tana pukapuka whakamutunga. Kua rerekē taua wāhi mahi i nāianei, engari kai reira tonu te wairua hihira o ngā wā o mua. E koi tonu ana ngā whakaaro o Pāteriki mō ana tūroro - arā ia hoki ki tā Ānaru Hāmuera kōrero mōna - he tangata kaitaki ia i te whakaarohanga pānga whakaora hinengaro o ènei rā, à, koia rā ka tukua e ia kia pā ki tōna whaiora.

Keywords: psychoanalyst; learning; experience; patient; analysis

\section{Introduction}

Some years ago, a friend of mine moved to London. Soon after, he got to do some work for a man two houses down the road. The person was a psychotherapist who was writing another book. My friend wondered if I had ever heard of him...

Time passed, and I went to visit my friend, who asked me if I wanted to interview his

Mercado, G., and Casement, P. (2020). Meeting the man we are learning from: Interview with Patrick Casement. Ata: Journal of Psychotherapy Aotearoa New Zealand, 24(1), 43-56. https://doi.org/10.9791/ajpanz.2020.04 
neighbour. When adventure calls, I tend to say yes first, and think about it later. This is how I found myself sitting in my friend's living room, meeting Patrick Casement on 10 September 2018. We conversed for an hour, and then he left saying he would let me know the time of the interview. In preparation for this encounter, I wrote a mind map of potential topics to talk about. I was more interested in following Patrick's lead than in directing the conversation. The following day I was welcomed into Patrick's home, where he has seen so many clients in his office by the front room. It is changed now, but the atmosphere is still filled with memories of all the people who had once been there with him.

Gabriela: One of the key concepts you developed, practised, and wrote about is trial identification, as part of the therapist's internal supervisor. Would you use trial identification with the patient's past experience and/or with their experience now, in the room?

Patrick: When I talk about trial identification with the patient, although we can think of that in terms of trial identifying with the patient in his situation out there, that's not the main reason I use this. It's more in terms of trial identifying with the patient in the session. This patient, with his experience and sensitivities, may hear me quite differently from how another patient might hear me. I have to try and choose how I speak to this patient to take his life experience into account. A patient may have experienced other people blaming him for his situation or criticising him for it, so we need to be very careful how we approach this, so we don't sound as if we too are criticising the patient or blaming him. And what really doesn't work at all is to try and reassure the patient with negative "I'm not thinking of you critically, I'm not blaming you"; the idea has crossed my mind, but I quickly cross it out, however the patient hears you before it's crossed out... And a lot of people use the negative as their way of trying to say they're not like that.

Gabriela: Yes, but surely a patient can't hear that; they will hear that you are like that.

Patrick: Well, they'll hear two things; they'll hear that we want to be seen as not like that and they may play into that... They may respond to us taking into account that we come over as needing to be seen as not like that. Whereas, what about the extent to which they may actually feel we could be like that... and so rather than [saying]"I'm not like that" [I would say] "I think I'm hearing some anxiety that I too might be like that" which is quite different. That's using trial identification with the patient in the session. And it can make a big difference, because we're leaving room for the bad experience, that experience in relation to us as well. We are not eliminating that; we are not coming across as needing to be seen in good terms. So, with my burned patient [refers to Mrs. B, Learning from Our Mistakes, 2002] I would never say, "You experienced your mother's collapsing but I'm here and I haven't collapsed," I would say, "You've experienced your mother's collapsing and I keep on sensing that you are afraid I too might collapse." I can bear to be experienced in those terms, small difference but big difference.

Another example of a small difference that can make a big difference to 
the patient: the patient is talking about something difficult in the session, and we might get into sensing there is history in this and say "I think you experience me just as you experienced your father - down in memory lane," so we make a connection from the present to the past, following the direction of an interpretation away from us into out there, rather than, "You experienced your father like this and I think you are afraid I too could be just like that." It's picking up the same connection but from his past into the present: small difference but big difference.

Gabriela: You worked for many years in this profession that, in my view, can be lonely, and challenging. What kept you going?

Patrick: I l kept working because it was often difficult. There was a challenge, and I think in a lot of my work I was on the edge of my chair rather than sitting back. I expected it to be difficult. If it's easy then I'm not really listening. I could get into "I've heard all this before," and out would come a few more clichés. I've used them before, I'll use them again, but that means nothing... and I learnt to be slow in making connections. I would like to leave space for the patient to find connections.

Like the patient who came very excited by her work with the previous analyst who went into all her stuff about Oedipal attachment to her father and she expected me to do the same kind of cliché work with her and I didn't. Then she had these two dreams about Kojak. ${ }^{1}$ In one, Kojak was flirting with her and taking her into bed but, unfortunately, she woke up too soon. Mind you, all the best dreams end too soon. And then there's another dream about Kojak in which there is a bathroom with many baths, and she remembered exactly where the bedroom was when Kojak was trying to get her into bed. It was when she was four years old, they lived in that house for one year. And I just said to her, "There's something about Kojak, he's appeared in two dreams." "I don't know what it is about Kojak, except I think it's something to do with his bald head... I really fancy him. I don't know anybody with a bald head...” - shock - "but I saw my father once when he was asleep, and he had a complete wig, a complete toupee." So, here was the hidden bald head and the connection with the father. And then a dream in the bathroom where there were many baths, like in a school with lots of baths in the bathroom. And I just thought maybe there is an unconscious metaphor for frequency, many baths... and she shouted "ah" and she remembered that her father used to wash her between her legs in the bathroom, frequently, until her mother caught him doing this and she banished him from her home when she was four. He then went and eventually married a girl when she was a teenager. He married a girl of her age with her name, so she discovered the abuse herself rather than because someone was coming up with clichés.

If we think we understand it can so often get in the way of understanding. It's a lazy way of understanding, you don't have to do the work. We have to be

1 Kojak was an American police detective show in the 1980 in which the lead star, Kojak, solved crime and sucked on lollipops. 
patient to find out. It's our impatience to think we understand; "of course this is what this is about"... more clichés.

Gabriela: We stop thinking, and I reckon staying in that place of accepting that we're not understanding, avoiding the clichés, it's a place of uncertainty. It's a place of being open to what sometimes can be quite scary.

Patrick: $\quad$ Yes, but I think there are different ways of speaking of not understanding. A patient could hear us as saying "I don't understand" (laughs) rather than "There's something here we still need to try and understand." I'm not switching off from understanding, we still need to try to understand.

Gabriela: You're leaving something open...

Patrick: Yes...

Gabriela: And also talking about the connection there....

Patrick: $\quad$ Now, I mentioned yesterday about the patient I talk about in my first book (On learning from the patient, 1985). I had to tolerate having a patient coming to me through her brother in law, who was a doctor. He was trying to be in control of her treatment. He was trying to use medication, which didn't work; he got her jaws wired, which didn't work. And I chose not to try and control any of this although he was making a nonsense of the analysis. All of this was a destructive attack upon the analysis, which the brother in law didn't believe in. I would take the line of: "Well, you have to decide whether you go along with this. Maybe you have to find out for yourself if it works." Letting her have the freedom, until all of these things have failed, and eventually I happened to use the phrase, "I think what you are discovering is that you need to find your own version of yourself, not somebody else's version," and this absolutely fitted for her, and it became her thing, that stayed with her forever. She had to leave after 15 months because her visa ran out, so we had a very brief time, but it completely transformed her life in that short time. She said she had discovered that she didn't need to eat compulsively anymore, except she was going to because she didn't want to start losing weight while she was still under the control of the brother in law, because it might look to them - her mother and the brother in law - that their control of her was working, so she kept her weight on until she left the country and then she let it fall away. "My secret is I don't need to do this any more but I'm not going to let them know."

It's funny because somebody reviewed my book, I don't know if it still happens, but there was a $\mathrm{BBC}$ overseas radio station that would have programs for English speaking people around the world, and they reviewed this book and this patient's mother happened to hear the book reviewed. By this time the mother seemed to have learned that the patient seemingly felt there was some value in psychotherapy, so the mother said: "I've heard a book reviewed on the radio, you might be interested, it's by somebody called Casement" (laughs) and the patient then I think said to the mother: "He was my analyst." Gabriela: (laughs)...

Patrick: But one of the things in common, for most of my work where something truly transformative happened, I think it's true to say, is that in none of them did I 
really have a sense of where was it going to go. I had to travel with the patient and see where it went...

Gabriela: Is that because you feel patients often come wanting you to tell them where it is going to go. It's like they're saying, "Okay, fix me, what are you going to do with me?"

Patrick: Well, the patient is often looking for the therapist to have answers. What I think we have to hold onto strongly that any answer that could be found is in the patient. "We somehow have to work towards you finding your own answers, I can't find them for you, but maybe I'll help you find your answers within you.” Which I think is something very different... but people do like the idea of a shortcut.

Gabriela: Yes, some people don't like not to know how long it is going to take, and prefer something like CBT.

Patrick: Yes, if you want answers you find people who offer you answers and see if they work for you.

It's very funny, when I had just come out, after five months in hospital with cancer (see Casement, 2018), somebody suggested that I take part in some project where I allowed them to interview me about my cancer experience. I said I'd be very happy to talk about it. Somebody then came to me; he was very pleased that I was going to be in his project. I said: "I'm very happy to talk about my cancer but what's this project?” He said, "Well, first of all you'll be interviewed and then you'll be given six sessions and interviewed again. Then, six more sessions and a final interview assessment." And I said, "What is this about?" and he said, "Well, we think we can help you find answers to your problems." And I said, "But I don't have any problems at all with the cancer, and if I did, I'm not sure as a psychoanalyst I would necessarily come to you lot to find answers." "Oh, you're a psychoanalyst, I better not put you on my project.” (laughs) It's true, I actually had no problem with my cancer. It was an absolutely extraordinary experience. I could say that I would prefer not to have been through it but I'm not sure I believe that.

Gabriela: Why?

Patrick: $\quad$ I gained so much from going through it; I can see a lot very differently, and if you want to understand what life could be like for someone who is completely paralysed and can't move anything except the eyes and can't speak, one way of finding out is to be in that situation, which I was...

Gabriela: In your book Learning from Life (2006)you talk about purpose in psychotherapy, I wonder if you could say more about that?

Patrick: I suppose what I mean is having a sense of direction, what's it all for?

Gabriela: Who for?

Patrick: Well, it's only going to make sense if it's for you. If you are fulfilling somebody else's purpose you're not fulfilling your own. The purpose of my life, as far as my family was concerned, was that I should become a naval officer, like my grandfather, his three sons, and my brother. The whole purpose of life was to become a naval officer. Their purpose for me was to be something completely 
alien to myself. So, could I find my own purpose in life, my own direction? It became really essential for me. For instance, when I applied to the Institute for training, I wasn't going to conceal anything from them. I didn't want them to find out halfway through my training that I had been in a mental hospital for four months, so I told them and said that my interest in psychoanalysis really started there. If they didn't like it, they didn't have to take me. Because if they took me, they needed to take me as me. I was not going to present what they might be looking for, because I would feel they hadn't really accepted me as me, but me as some version that I seemed to think they wanted and I wasn't prepared to play that game. It would be a journey into being unreal, again.

Gabriela: It's taking the risk of not being accepted, not just into a training but not being accepted by your own parents, not being accepted by your own kind...

Patrick: I think sometimes they may have regretted having accepted me, because I continued to insist on being real and speaking my mind, even when it was not convenient for them to have me speaking my mind. I had come across things which I think are seriously wrong. For instance, in my paper about the Emperor's Clothes (2005) I said there are some serious dangers in the training, that people get caught up in the power differential between the trainers and the trainee and so on, and the training analysts being able to hide behind their superior position, they seemed not to look at themselves. I stand and speak for these things which is not what they expect of one of their training elders, standing up, being critical of the training analysis. "Now, if we had known we wouldn't have made him a Training Analyst" (laughs). There are lots of things to criticise and I think it is more effective if it can come from inside the profession rather than from outside. I'm from the inside and I think I do know what I'm talking about, and I would like to be listened to. And some people have listened to me, quite a lot of people actually, but it took my society a long time to begin to look at what I wrote as I was saying in Learning from Life (2006). It was at least into the second year after my first book (On Learning from the Patient, 1985) came out that one or two training analysts said to me, "What is this book that my patients tell me I should read?" (laughs)

Gabriela: I was also thinking about dependency, and how we become dependent on this work we do...

Patrick: I think we need to be aware of the risk of over-dependence from a patient, and equally our dependence on our patients. Because to some extent we depend on our patients for our own validation; and when patients feel ready to leave, we may not be ready to let them go. In extreme cases there are some people who hold onto their patients because they haven't got an adequate pension, so their patients continue to be their pension. Somebody [a therapist] came to me for consultation, when I was quite junior, so he chose a junior person to come to, and confessed that he had a patient who had been seeing him for years who is dependent on, not only holding his finger through every session, but sucking his finger in every session, and he let it all happen. I said to him, "We have to face the fact that this therapy will never come to its real end until 
you get beyond this collusion," and he said, "I don't want it to come to an end, she's my pension." That's an abuse of the patient. I was too junior to report him, I felt I wasn't in a good position to report him, which is, I think, why he came to me and he heard what he expected me to say, and he could ignore it.

Gabriela: When and how did you decide to stop working?

Patrick: You want a real answer?

Gabriela: $\quad$ Yes! (laughs)

Patrick: $\quad$ For years my wife had wanted to move from this house and I absolutely refused, because I had so many moves in my childhood. This is the one place that has stayed the same. I felt it would kill me if I had to move... unbearable. Eventually my wife used to say, "The only reason we're still here is because of your bloody patients," so when I was 67, I made a decision. I said, "I'm going to let my patients know that in three years' time I want to stop working," and so they got three years to adjust to that or to prepare to move to somebody else. And then if we're still here and I'm not seeing patients it must be for some other reason than bloody patients (laughs). We are still here 13 years later.

Also, I say this as a joke, but both bits are true, I didn't want to die on my patients. I also didn't want to find myself still seeing patients years after I died. That was stimulated by meeting an ex-supervisee in Waitrose. I went up to her and said, "Hello, J." "Do I know you?" she said, and I said, "Well, you used to know me because you used to come to me for supervision", "Who are you?", and I said, "I'm Patrick Casement". "Ah I'm glad I have met you! I'm 89 , and I'm still seeing patients, so please refer," to someone who couldn't even remember who I was! She was still seeing patients years after she had died.

Gabriela: It's a big decision.

Patrick: Yes, it is.

Gabriela: Was it hard?

Patrick: $\quad$ Yes, I would say much of my life was based on it. I had to work hard on myself to let them go. That wasn't easy.

Gabriela: Did anyone refuse?

Patrick: $\quad$ Refuse to stop?

Gabriela: Yes...

Patrick: I didn't give them the option to refuse to stop, but I could refer them on to somebody else if they needed to do that. I don't think I realised, while I was still seeing patients, the burden that we carry. So many lives we carry on our shoulders. I don't miss that, and I don't miss the early start every morning. I used to start every day at 7:30 and worked from 7:30 to 10 [minutes] to 8 . Somebody said, "You only work 20 minutes a day?" (laughs)

I discovered early on that, when I was a student, the process recording of the sessions was valuable. But also I discovered a problem with it: because I'd be hearing something today from a patient, which I knew linked to something that occurred last week, but I couldn't remember the detail, so I looked at the notes, and it would come back with my memory refreshed a day late. I began to realise my memory was in the wrong place! It was in my notes, I needed it here in the 
room. So, when I stopped my training, I didn't have the requirement to write notes, I thought, the unconscious is an amazing thing and memory is an amazing thing, trust it. I trusted my memory to remember sessions, and when I needed something from a memory, I found in a session several years later, I would remember it. Just like that dream you had when... whatever... I was thinking of the same thing just now... whatever the patient is saying... so my memory would respond to the here and now of our session, with the memories that might belong to this session. Quite often I would think: "I'm seeing Miss X next, but I can't remember anything about it at all.” The patient will come in, get on the couch and the session would be there. It would come back to me.

So, I learned to trust my memory and so, with very few exceptions, what I have recorded in my books are remembered sessions. Because doing the work establishes the memory that goes with doing the work, so I just follow the sequence that we've been through, and the memories would come to me. When I put the last book together, I knew I would be quoting from something that I published in one of the other books. I began to think, "Oh, I must get that book out and find the place and copy it out." Why? I'll just write it again, it won't be word for word, but the essence will be there. An earlier version appears in such a book, but I haven't looked it up.

Gabriela: You just remember...

Patrick: $\quad$ Yes and mainly it's a gift. It was very valuable to me.

Gabriela: Did you write notes anyway or you didn't?

Patrick: I wrote down addresses, phone numbers, names, ages of children, or siblings, ha! I had an Irish patient who came early on. She was laying on the couch, and she had about 14 siblings, and I started writing all these on my hand. When she got to the end of the session I said, "See you tomorrow" (laughs) but apart from that I didn't write anything.

I know that I was probably not legal being without a record. But I wasn't going to be dictated to. I wanted to work in a way that made most sense to me. I also resisted joining CPD groups, because I didn't want to have my work influenced by other people's ideas. I was depriving myself of the benefit of other people's ideas but I felt they could be interfering. I really wanted to stay listening and learning from each patient without the listening being distorted by other people's ideas of what I should be hearing. Now, it's probably limited me in lots of ways, but I think it also enriched my work in a different way. It's had its own validity rather than all these American theories, which I haven't read. I could apply all sorts of bits, but I refused to do that. Equally when I wrote my book, the publisher would send it out to reviewers before accepting it. I would only offer a complete manuscript. I would never let them interfere with my writing: “This is what I've written, do you want it?” Sending it out to the readers, it would benefit from a review of the literature, compare and contrast, all that jazz, which would kill my book, making it a book I wouldn't want to read (laughs). I refused all that stuff, and I think it allowed me to remain, truly, more authentic. What I wrote, what I did, and what I said to my 
patients which is what my professional life has been about. I protected it from interference as best I could, and I stand by it for all its faults and inadequacies.

I'm dreadfully ignorant of all the theories that I should be reading and should have read. I know there are parallel theories in America, but I can't tell the difference between this kind of object theory and that kind of object theory. You have to be a scholar to see the subtle differences, to hell with the work, I'm not interested. I should be but I'm not, I'm not a scholar, or I'm not that kind of writer.

Gabriela: And it's true, reading your book I felt your presence, you were there with me. I really felt less lonely working... it was nice. You are working on a new book? Would you like to say something about it?

Patrick: $\quad$ It came as a big surprise to me. I had no intention of writing it. I didn't believe it would work as a collection of papers. It was after I'd had a fall, and only because I had the injury and was confined to bed for some weeks, that I sat with my computer and began looking at the possibility that it could work as a collection. I began to discover, to my amazement, that somehow there are threads that follow through from one paper to another paper. I thought, "Well that's what it's all about!" and I became quite excited that it was beginning to fit together in a way I never imagined it would. Then it just took off, but it was also mostly unprepared. I didn't know it was happening.

I wrote a thing called Ways of Working (2017) because I noticed that all the significant members of my society were written up on the Internet, and I wasn't included. It didn't surprise me because they had often wanted to sideline me in my society. My wife thinks they're envious that my first book got 45 reviews, which is not what they get (laughs). Anyway, they decided it was an oversight, I was told, but someone was going to write me up. I thought who is going to write me up? Someone who has never met me, won't have read my books, won't be in position to pick some ideas out of them, and think these are significant. I thought, which bits do I think are significant? And I just wrote down on some bits of paper what I would like to be remembered for. I put three pages together and offered it. Within weeks it was accepted for the International Journal. Then I thought, if I do collect my papers together, I've got something here, a starting point. And things sort of developed around it, this was February, we're now in September and it's coming out the end of next month.

Gabriela: Brilliant!

Patrick: Yeah, and I couldn't believe that anything I wrote could get endorsements like I got for this book. I'm just amazed and hugely grateful to be profoundly validated by all that.

Gabriela: It's the recognition of your work and your life.

Patrick: I think I told you how I came across the title of my first book, that I wasn't writing a book... I didn't want to write a book. Jason Aronson in New York wanted me to present a manuscript, he seemed to think I had a book in me. I didn't want it; he was a publisher and I didn't want to write a book. I didn't 
Gabriela: $\quad$ It's your brand?

Patrick: $\quad$ Yeah, my second book was going to be Psychoanalytic space and process, no, it's got to be Further Learning from the Patient (1990). Learning from Our Mistakes (2002), my working title was Getting There, which I used for the first chapter. "No," says the American publisher, it's got to be Learning from Our Mistakes (2002), okay, good title. Learning from Life (2006) came naturally. This last one was going to be called On Being in Touch. "No", says the Japanese translator who's done four books in Japanese already, we want Learning from..., so Learning Along the Way (2018). And it all happened...

Gabriela: And it all happened...?

Patrick: $\quad$ And in each case it's as if I've been taken over by something which is me but doesn't feel completely me. Because I hadn't quite chosen to do it; it sort of happened. I could never write unless it flowed. So many times, I was writing a chapter, and then into another chapter, and I get to ten pages into it and I think, "this is rubbish". I tear it up and the muse was not with me, I'd started in the wrong place. It wasn't going anywhere, so scrap it. I had no obligation to write, I had no publisher giving me deadlines, which would be killing me, so I just stopped writing until something sparked me. I never planned a chapter; I would see where it went and I would get quite excited with where it was going. It sort of led me along the line, each chapter wrote itself really with a little bit of help from me.

Gabriela: So you follow... you don't call it intuition (laughs) but it's a bit like that... it's your sense?

Patrick: If I had any talent in writing I think it was being able to recognise when the muse was with me. When it wasn't, and when it was turning out rubbish, I thought, "Well, the waste paper basket is the place for that." Never mind I'd spent hours and hours writing rubbish, I'd start again.

Gabriela: What have you enjoyed the most of your work, and what have you struggled the most with?

Patrick: I think Learning from Life (2006) is the book that has meant most to me because it brings a lot of things together. It's where I come from, it's what makes me me. The journey of becoming more real than I was. Also discovering what laid behind the defense. I was completely frozen, I had no feelings of any kind really, I had no sense of attachment. I can remember going to a weepy film and I couldn't understand why people were crying, it's only a bit of celluloid. I couldn't tune into other people's feelings; I couldn't tune into my own until I bumped into some feelings which my God! I really thought I was going mad. In one of the first two chapters of Learning from Life (2006), when I suddenly 
found myself crying... I never cried. Years later, discovering it was in the area of attachment that I'd been so damaged, because each attachment I made ended with that person leaving. It was safer never to be attached again, which for years I wasn't. By being able to get past that need to be shut off from the pain of attachment, and through the fulfillment of attachment, I began to come alive.

That's been one of the most exciting things, to have been able to come alive, and to be able to enable other people to come alive. It's been absolutely thrilling. I'm not going to try and pick out particular cases, because so many have been profoundly affecting me, but none more so than Mrs B which was such a totally extraordinary experience (sobs, whilst picking up a tapestry cushion from an armchair next to him). She made this, it has fourteen layers: one, two, three, four, five... she came for fourteen years. That was her gift to me (cries). I'm so grateful to have had that experience and so is she. I mean, I think few people have the privilege I had with her to be drawn into such profound and painful experiences, and to be able to make sense of it. And to have, which you read in Learning from Our Mistakes (2002), the totally extraordinary validation, that she came across towards the end of the analysis, when her mother explained what lay behind this memory, the not holding her hand... unbelievable (cries). Other people had thought, "Why was she making such a meal of that moment when her mother fainted?" Just not holding my hand, why make such a thing about that? And why was I putting her through all that? Couldn't I have made it so much simpler and easier for her, and less painful, by simply holding her hand to bring it all to an end? But something, absolutely all the way through, was cautioning me not to destroy what was in process. It was there for some reason, we didn't understand what it was, but it was there for some reason. I must stay true to that... oh, it was so difficult! It was so well worthwhile! And to have it validated by the mother coming up with this bit of history we didn't know, and yet we'd been living it between her and me. We had been at it all the time and couldn't quite recognise it, until she was ready to hear it from the mother. She lived all her life with her mother who nearly killed her, but through the analysis she found out that her mother had also saved her life. Later on, she was able to nurse her dying mother through that dying, which would never have been possible had she not been through the analysis. So, you can't be that surprised if that's one of the most incredible experiences of my life.

But I do mind that there's something about the quality of that that is too challenging for too many people who dismiss it for all their own reasons. They've written all these critical papers, about it dismissing it, for their own reasons, and missing for themselves the richness of it which could help them to work differently. If only they could bear it... but I don't think they can. Anyway, to have had that opportunity was such a privilege, and I know perfectly well if it hadn't been for that work with her, I would never have dared to believe I had a book that could come together, as worth offering to a publisher. It was my work with her that got that first book going and it's she 
Gabriela:

Patrick:

Gabriela:

Patrick:

Gabriela:

Patrick:

Gabriela:

Patrick: who got me on the map, she who introduced me to audiences all around the world and here are some of the books (pointing to the bookshelves). What a gift!

What a gift!

I just hope other people can recognise the gifts that they have in the work they are privileged to do with their patients. It is a great gift to be allowed to get to know somebody more intimately than they have been known by anybody else. What would I have done with my life if I had not been an analyst? I couldn't imagine anything more fulfilling... and I got there because I began to realise that I felt a fraud working as a psychotherapist. I was seducing patients into getting better for me, like with my earlier therapist, getting better for her. It was all false, there must be something better than that, and there is.

The therapist needs to be able to tolerate and survive the patient's anxiety of getting fixed...?

Yes, I can remember years ago meeting somebody who had had analysis and said, "Oh, I finished my analysis years ago," and I found myself saying, "Finished your analysis?" I believe that if analysis really works it continues indefinitely in us however long we live, if we let it; and if we let it, we can end up somewhere quite different from where we got to in the work we started with our analyst. We end up somewhere quite beyond that, because there's a process that takes us there. I am here, very different from my analyst, as a result of the work I was doing, inwardly as well as outwardly, and the process stays alive if we let it stay alive rather than, "I finished eight years ago," why kill it off?

Yeah...

Anyway, have we got there?

Yes, I think we've got somewhere...

Getting there... After my first two books, I was never going to write another book, but our daughter gave birth to our first grandchild, whose life was seriously at risk for the first 10 days of his life. He only had a quarter of his lung capacity available to him, it had all filled up with black tar because he went into stress in the womb. There was almost no chance that he was ever going to live, really. The doctors said to our daughter, "We must be honest with you; he's going backwards and there is no backwards to go," but he came through. I can't remember quite exactly what I wrote, but on the way back from seeing him in Australia, I found myself writing something like, "When the future seems most impossible, it's getting there that wins the day." I thought, "For you little boy, I'll write another book" (Learning from Our Mistakes, 2002) and I dedicated it to him with those words. The poor lad is in hospital again right now, having broken his arm very badly indeed, so bang! goes all his plans to be swimming and surfing and all the rest of it. He's a lovely boy, he's 17 now, and when we were in Oz last time, he took us to supper, drove us and paid for supper. Life goes on, it's wonderful, wonderful!

Thanks for taking your time. 
I stopped recording. Patrick then told me how his daughter decided to move back to the UK from Australia, when her (then) two sons were still small. They had sent the children's toys, and then they came to New Zealand for a last holiday. But it was raining almost all the time. Then the little boy asked his mother, "Where has the blue sky gone?" He was used to it being sunny, in Australia. And then he asked, "Will it be like this - all rain - in London?" His mother felt she could not do that to him, moving from a warm and sunny Australia to a less clement climate. My own choices of living away from my parents became present in that moment, as I could feel a father's sadness in his voice. Patrick held my hand whilst I thanked him for this wonderful hour, an experience I will always treasure in my heart.

\section{References}

Burton, E. S. (2017). Patrick Casement. Institute of Psychoanalysis, British Psychoanalytical Society. Retrieved from https://psychoanalysis.org.uk/our-authors-and-theorists/patrick-casement Casement, P. (1985). On learning from the patient. London, UK: The Guilford Press.

Casement, P. (1990). Further learning from the patient: The analytic space and process. London, UK: Routledge.

Casement, P. (2002). Learning from our mistakes: Beyond dogma in psychoanalysis and psychotherapy. London, UK: Routledge.

Casement, P. (2005). The emperor's clothes: Some serious problems in psychoanalytic training. International Journal of Psycho-analysis, 86(4), 1143-1160.

Casement, P. (2006). Learning from life: Becoming a psychoanalyst. London, UK: Routledge.

Casement, P. (2017). Ways of working: A synopsis of contributions to psychoanalytic technique. International Journal of Psycho-analysis, 98(6), 1813-1816.

Casement, P. (2018). Learning along the way: Further reflections on psychoanalysis and psychotherapy. London, UK: Routledge.

Casement, P. (Anticipated publication date: March 2020). Credo? Religion and psychoanalysis. London, UK: Aeon Books.

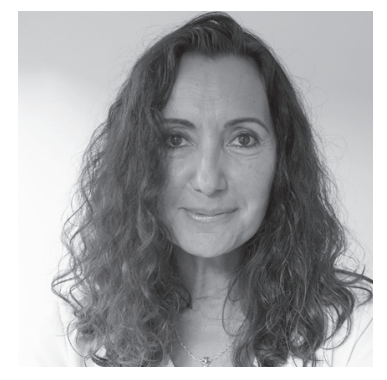

Gabriela Mercado is a psychotherapist, sex therapist, and supervisor. She works in private practice in Auckland. Gabriela has worked at the New Zealand Aids Foundation Burnett Centre, and at Auckland Sexual Health Services (ADHB). She is an active member of the New Zealand Association of Psychotherapists and is a Council member for the organisation. Gabriela has presented her work at the Prostrate Cancer Foundation National Conference and has been a guest lecturer for AUT University Masters of Psychotherapy. Contact email: gabriela@orcon.net.nz 


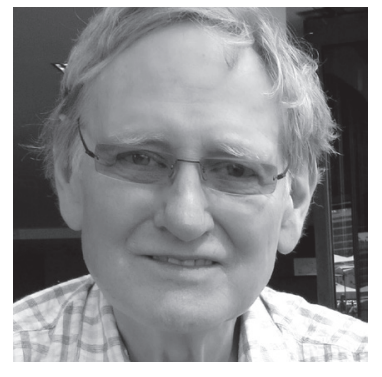

Patrick Casement is a British psychoanalyst and author of multiple books and journal articles on contemporary psychoanalytic technique. He has been described as a pioneer in the relational approaches to psychoanalysis and psychotherapy by Andrew Samuels, Professor of Analytical Psychology. His book Learning from Our Mistakes (2002) received a Gradiva award for its contribution to psychoanalysis, and his book Learning Along the Way: Further Reflections on Psychoanalysis and Psychotherapy (2018) was listed in the top 100 psychotherapy books of all time by Bookauthority. Patrick Casement is best known for his Learning from... series. His works have been translated into 21 languages and utilised by psychoanalysts and professionals from other related disciplines. Burton (2017) highlights how Patrick Casement identified learning from his patients in the analytic encounter as being of central value in his work as it allows for continuous discovery and understanding. His most recent book, Credo? Religion and Psychoanalysis is due to be published in March 2020 by Aeon Books. 